\title{
Effectiveness of Nature Conservation - A Case of Natura 2000 Sites in Poland
}

\author{
Małgorzata Grodzińska-Jurczak, Marianna Strzelecka, \\ Sristi Kamal and Justyna Gutowska
}

Additional information is available at the end of the chapter

http://dx.doi.org/10.5772/50664

\section{Introduction}

Accession to the European Union (EU) provided the Member States with new and extensive opportunities for policy development as well as changes in the management of their national, regional and local economies. The EU Member States had to implement standards of the European Union law, which included a broad spectrum of principles of sustainable development [1]. Specifically with regard to nature conservation, the European policy strengthened the implementation of a rational development strategy by influencing the Member States to adopt international commitments such as the Convention on Biological Diversity, and through the expansion of nature conservation areas. Among the EU directives promoting nature conservation, the most important provisions were the Birds Directive and the Habitats Directive. Implementation of these two directives subsequently gave rise to a new form of nature conservation - the Natura 2000 European Ecological Network.

At the regional level of the EU, the general principles and the implementation of the nature conservation policy are complex and governed in a top-down manner. Such approach is inherently at risk of being introduced locally with a low level of effectiveness and adaptability. Hence, current mechanisms of nature protection (mainly biodiversity) in the EU need to be complemented with effective bottom-up initiatives in addition to new means of top-down approaches. The latter appear to be essential, particularly in the new Member States where nature conservation is still affected by the post-socialistic governance and it operates in a rather ineffective way [2].

Recognizing the importance of and integrating the social dimension with the ecological needs, we observe a slow shift in the nature conservation paradigm toward increasing the participation of local stakeholders for more locally sustainable outcomes [3]. For locally 
sustainable environmental policy solutions, stakeholders' participation in nature conservation is essential. One of the issues evident from the practice of countries that introduced the new nature conservation policy - the EU-25, seems to be the involvement of the possibly large group of stakeholders at all levels of decision-making (local governments, communities, business, non-governmental organizations etc.), but with special attention to local level processes related to the Natura 2000 Network [4]. Within the sustainable development paradigm, the EU public participation is both means to achieve sustainability and the leading principle of rural development.

The concept of nature conservation has changed from strictly traditional, biophysical perspective towards a more innovative approach that integrates the protection of flora and fauna, and habitats with social and economic activity [5-7]. However, natural resource conservation in Poland has been traditionally focused on the preservation of natural environment without deeper consideration of the interests of local stakeholders, who are an important component of those environments. Development of policies concerned with environmental protection adopted the top-down model of decision-making, which implies that stakeholders such as local authorities, environmental groups operating in rural localities as well as owners of the private land under protection have little impact on land designation and management. The authors seek to develop a report based on the available studies and the authors' experience with the European Ecological Network - Natura 2000 that builds the discussion framework to examine problems emerging due to the designation of protected areas as well as implementation and management of the Natura 2000 in Poland.

\section{The ecological network natura 2000 in the European Union}

The Ecological Network Natura 2000 is the most recent form of the nature conservation strategy implemented in the European Union Member States. It differs considerably from the previous traditional protection system in that it aims at halting the biodiversity loss and maintaining or reconstructing the favorable nature conservation status by protecting natural habitat types, besides protection of floral and faunal species that are unique in the European continent. The popularity of the European Ecological Network after this time period is still debatable $[8,9]$. It includes sites designated according to two nature conservation directives of the European Union. Bird Directive (79/409/EGK) accepted in 1979 refers to specific birds' habitat as Special Protection Areas (SPAs), while Habitat Directive (43/92/EGK) from 1992 led to designation of Special Areas for Conservation (SACs). As a form of area-focused environmental protection the Natura 2000 is the first international network at a continent scale that is managed independently at the national level. Currently it comprises over 26,106 sites and covers $17.5 \%$ of the territory of EU Member States [10].

The beginnings of the Natura 2000 reflected the changing approach to the structure and functioning of especially valuable natural landscapes in European Membership Countries. At first the process of designating Natura 2000 sites was slow due to the lack of agreement on the methodology to evaluate site proposals. Many EU Member States were subjected to legal proceedings for their slow designation rates [11]. Scientific criterion for the selection of 
sites for Natura 2000 was agreed as the only criterion for choosing the Natura 2000 sites, and these criteria are listed in Annex III of the Habitats Directive. Moreover, even though sites for the Natura 2000 Network were selected on the basis of the same designation criteria, the share of land selected for protection within the Nature 2000 Program significantly varies among the EU Member States. For example, it includes 7.1\% of the country's area in the UK, $12.8 \%$ in Germany, $20.9 \%$ in Portugal to as much as $34.9 \%$ in Bulgaria and $35.5 \%$ in Slovenia [12].

The selection process reflects solely the ecological emphasis on maintenance of given species or habitat (these are for example: "size and density of the population of the species present on the site in relation to the populations present within national territory" and "degree of representativeness of the natural habitat"). Despite some consultations with the local governments and citizens about designating areas under the Habitat Directive, Natura 2000 has been viewed a top-down policy that is not considerate of the local communities' needs. Such a situation has led to two types of conflicts: a) vertical conflicts (disagreements between national and local or regional authorities) and b) horizontal conflicts between stakeholders from public and private sectors. In the vertical conflict, local authorities disagree with the methodology adopted to designate sites for the Natura 2000 Network, while horizontal conflicts of interests occur between public administrations such as General and Regional Directorates for Environmental Protection (GDEP; RDEP), which are responsible for implementation of the national law, together with local governments that conform to RDEP's instructions and entrepreneurs, land owners or other private sector stakeholders.

Several examples from across EU demonstrate man-nature conflicts during the planning and implementation of Natura 2000. Germany for instance, has had strong local opposition to the designation of Natura 2000 sites. Farmers depending on established systems for agrienvironmental schemes feared that these would no longer apply or become more difficult to access [13]. This fear resulted from little or no communication, due to the Länder (provinces) governments having underestimated the need for adequate stakeholder information and the associated administrative commitment [14]. Similarly, in France, the implementation of the network was questioned by a number of stakeholder groups (including important representatives from the agricultural, forestry, game and fish-breeding sectors) and ultimately caused the national suspension of the directive. In 1996 protesting groups drafted a declaration taking up the claims. While reasserting the fact that they were not opposed to the principle of conservation, they objected to the methods used to compile the list of sites and the extent of surface areas involved. They demanded the surface areas of the Natura 2000 sites to be reduced and financial resources to be allocated so as to compensate for the loss of earnings due to the new management measures [15]. Other examples of disagreements due to Natura 2000 include Finland, where the network caused major conflicts between landowners mainly lumberjacks and environmental authorities, and ultimately affected countrywide attitudes towards biodiversity conservation [14-16].

Apart from the conflicts related to Natura 2000 within Europe, the El Teide Declaration from 2002 highlighted the key factors crucial for successful implementation of the program, 
which included: "the success of Natura 2000 will require the support of European citizens, especially of local people and landowners, and their participation in the decisions on the implementation of the conservation and management of the areas involved". It also indicated that: "many of our valuable Habitats are the result of traditional land use and their conservation relies on traditional practices and skills". Current Member States and then the Candidates to the EU (Bulgaria, Cyprus, Czech Republic, Estonia, Hungary, Latvia, Lithuania, Malta, Poland, Romania, Slovakia, Slovenia and Turkey) that signed the document committed to "promote awareness and understanding of Natura 2000" as well as: "promote the development of partnerships involving the broad range of stakeholders in the conservation and management of Natura 2000 sites". Whereas in the "old" 15 EU Member States the conflicts between stakeholders in Natura 2000 have been mitigated, countries such as Poland continue to struggle with the program's arrangements, while looking for the most suitable solutions.

\section{Natura 2000 network in Poland - A success story?}

The problem of nature conservation in Poland is not new, but following the EU accession, the public participatory approach to biodiversity management has become a legislative requirement (Environmental Law - article 158; Act 2000 on Access to Information on the Environment and Its Protection and on Environmental Impact Assessment - article 4, 13, Law on Public Information). In this light, Natura 2000 Network has become a controversial issue in a number of rural areas. This situation usually happens when the principles of implementation of the European Ecological Network are considerably different from traditional forms of environmental protection $[17,18]$. Currently Poland, similarly to other Central Eastern European countries, is challenged by rapid social and institutional change, conflicts between traditions of centralized decision-making and new public values and concerns $[2,19]$.

From the very beginning, Natura 2000 Network in Poland caused problems with its' acceptance mainly due to the significant difference from a considerably well-established conservation system over the country and due to the ownership structure of the land covered by the new protected areas. In fact, only biological scientists placed much hope in the program, expecting it to make the protection of native species and habitats more effective on the strength of national legislation, if they are also protected outside Poland. Others, such as local governments of municipalities with areas covered by Natura 2000 Network and local stakeholders perceived it as a threat to local and regional socio-economic development. From their perspective, the program would introduce restrictions on developments in municipalities by creating barriers to usage of one's land and curtailing production and investments. A general negative attitude to the program has not changed much till now $[17,18]$.

The initial step to implement Natura 2000 Ecological Network already begun during late 90s, and the first stage was the preliminary analysis of habitats and species that would require protection. Poland was also negotiating for filling the gap in the EU policy about protected habitats and species that do not occur in any of the "old" Member States of EU 
and that had not been included in the contemporary nature protection systems. After the initial site identification process, the first phase of the Natura 2000 implementation in Poland focussed on designation and monitoring of the Natura 2000 sites. The boundaries of the sites included in Natura 2000 Network were primarily defined based on biological criteria, without seeking input from local societies or local governments [20-22]. The process was completed mainly by representatives of a few national research institutions and ecological non-governmental organizations (ECO-NGOs). In principle, protection objectives and methods should have been to some extent adapted to local social, economic and cultural conditions [23], however, the process did not consider the existing physical development plans. Moreover, the program's implementation plan did not take into account the possibility of social conflicts and consequently it did not provide for means of prevention [24]. Conflicts started to develop during designation of the sites boundaries and continued during the creation of individual areas' protection and management plans [25].

The Natura 2000 Network implementation procedures and timeline have been in force in Poland since the country's 2004 accession to EU, just as they had been in force in other EU Member States. The Polish Ministry of the Environment requested the local authorities to evaluate the boundaries of Natura 2000 sites within their territories. Majority of boroughs expressed a negative opinion of the designation process and its outcomes. They believed that the sites' designation methodology applied rather old-fashioned and un-professional consultation strategies in the form of one-way written opinion letters delivered to the Ministry by the municipal authorities. Neither did direct consultation with municipal governments take place, nor were they provided with any response regarding proposed changes [26]. Disregarding objections, in May 2004 the Polish national government forwarded the proposal of Natura 2000 Network to the European Commission. The updated version of the document led to strong opposition from experts involved in the creation of its first version. In response, several ECO-NGOs (Klub Przyrodników; PTOP Salamandra), prepared another proposal popularly referred to as the "Shadow List 2010" during the Bilateral Bio-geography Seminar in Warsaw, and independently sent it to the European Committee and the institution responsible for Natura 2000 operation in Poland: General Directorate for Environmental Protection - GDEP. Their list comprised of additional 33 sites Natura 2000 and modified boundaries of 22 areas. It consisted of land that needed to be added to the Natura 2000 Ecological Network according to conclusions from the seminar and findings from a number of projects funded by EU. The European Committee acknowledged both lists and a combination of both proposals (a preliminary and Shadow) was approved. The proposal of the Shadow List provoked further tensions between the ministerial authorities and the experts - mainly NGOs representatives, which one more time delayed the designation of the boundaries of protected areas.

The list was finally delivered to the EU Commission for approval in late 2009, after the Commission issued warning to the Polish government over its insufficient progress in implementation of Natura 2000 as well as a notice about violation of Birds Directive due to insufficient designation of Special Protection Areas (SPAs) [27]. Faced with a lack of response from the Polish authorities to these warnings, the EU Commission went to the 
Court of Justice of the European Union in Luxemburg. Determination of the European Committee intensified work on completion of the list of protected areas during the following years and Poland completed the list of Special Areas of Conservation (SACs) in 2010. Currently Natura 2000 Ecological Network covers $19.8 \%$ of the country. It includes 823 SACs and 144 SPAs for special birds' protection. The Natura 2000 forced some administrative changes in General Directorate for Environmental Protection. However, these changes in the management structure of the GDEP has had limited impact on management practices in Poland. Despite the fact that new governmental bodies are now responsible for the management of Natura 2000 areas (the General Directorate for Environmental Protection and its representatives in each province: Regional Directorates for Environmental Protection, directors of national parks, directors of marine administration as well as the Forest District), there is a gap in innovative strategies to decrease the friction between local institutions and agencies in implementation, management and monitoring of Natura 2000 sites. Although the agencies play an important role in the management process, the management efforts are still ineffective and it remains unclear what can be done to improve it. The authors seek to explain the most prevailing causes of the controversial nature of Natura 2000.

\section{Designation of Natura 2000 network in Poland - Conflicts and misunderstandings}

The tasks of the Natura 2000 Network are implemented jointly with provincial and local governments. Local authorities (Regional Directorates for Environmental Protection) are responsible for creation and administration of protected sites at the provincial level as well as monitoring and protection of floral and faunal species. So far, in Poland, protected sites have been established and supervised independently of local authorities. Although, the recently gained experiences have revealed many advantages of delegating some environmental protection responsibilities to local governments, officials have insufficient skills and limited budgets [28]. Natura 2000 Network was designated in 966 boroughs (out of total 2479 municipalities in Poland), and in some cases Natura 2000 sites cover surface of an entire borough. Thus, the engagement of different groups of stakeholders in nature conservation management should be one of the national priorities. So far there have been only a few promising initiatives from organizations such as Sendzimir Foundation [29] or ICLEI - Local Governments for Sustainability (http://www.iclei-europe.org) that supported the implementation of sustainable development principles in Poland by adapting a bottomup approach or community-driven development. Unfortunately, there aren't any bottom-up initiatives addressed in communities within the Natura 2000 sites as well as the areas that border with Natura 2000 Network.

Taking under consideration the limited time to oppose designated boundaries for land protection, it is reasonable to state that the designation of protected sites occurred without prior consideration of the local views and stakeholders' needs. In fact, no public consultation or other form of participation in decision-making took place [17]. Only in few 
regions (mainly southern parts of the country), selection of Natura 2000 sites was conducted via opened public consultation aimed at incorporating a broad spectrum of actors (local stakeholders, private landowners, NGOs). In these cases, borders of sites proposed by the nature experts were negotiated and finally changed according to the locals' suggestions [30].

Currently, Poland is in the second phase of the Natura 2000 Network - characterized by development of management plans for designated protected sites. These plans seem to be especially controversial as they have direct effect on boroughs' local economies. Residents as well as other stakeholders were forced to maintain the habitats requiring active protection in their proper condition due to the Natura 2000 Network requirements (e.g. intensive or extensive agriculture activities). However, due to a top-down approach their interests in collaborating on development of area management plans had been neglected. Active protection on private lands is impossible without prior agreement and support of landowners [26,30,31]. As much as public consultations are anticipated before development of protection plans in Poland, it is still confusing which tools will be used. Also, the effectiveness of such consultations as a form of stakeholders' participation in environmental decision-making is questionable.

\section{Compensating boroughs' economic loss due to Natura 2000 network}

Long-term sustainable development has not been and will never be easy for peripheral areas due to low quality infrastructure, low levels of entrepreneurship, as well as residents' mobilization and no motivation for joint actions [32]. To date only few studies have shown evidence of Natura 2000 having negative impacts on boroughs financial condition. However, it is clear by now that formal limitations due to the Ecological Network impact rural economies, including a borough's income. More and more local leaders demand reimbursement for costs of protection of habitats and species [33].

Local governments associated in Rural Communes of the Republic of Poland [42], proposed the introduction of ecological fiscal transfer. The essence of this financial tool is the redistribution of funding from national to local authorities to compensate for income loss for some local governments due to the large share of protected land. Such a financial tool has been successfully introduced in Portugal, Germany and Brazil [34-36]. Other countries that have not introduced reimbursement programs, attempt to deal with ownership conflicts within the protected areas (the most commonly in newly established or enlarged national parks and Natura 2000 areas) by employing tools such as negotiations, mediations or financial compensation. These solutions are most common in Great Britain, France and Finland $[8,15,37,38,39]$. Yet, none of the European countries has created a solution that would satisfy all stakeholders. Ecological fiscal transfer in Poland would let the municipalities manage their Natura 2000 sites in an effective way [34,40-41]. Also, similar initiatives could be the first step in undertaking a participatory approach to biodiversity conservation in Poland, while responding to much needed change in environmental management. 
The Rural Communes of the Republic of Poland whose municipalities are included into Natura 2000 Network raised an official objection, protesting against short notice to formulate opinions, use of pure scientific criteria (marginalizing economic and social aspects) while selecting the protected areas, and the system of financing Natura 2000 (no economic schemes to encourage local authorities and private owners to support nature protection or to compensate lost profits) [26,30,42]. Due to ineffective top-down distribution of funding resources for completion of the Natura 2000 tasks no resources reached the localities [40]. The opinion of the Supreme Control Chamber is that the funds management has been insufficient, and the current spending on Natura 2000 is underestimated as the expenses of a variety of institutions (e.g. local governments, NGOs, national parks and National Fund of Environment Protection and Water Management) were excluded [41].

Dissatisfaction with the implementation of Natura 2000 Network led to consolidation of local governments and taking an initiative on the above mentioned ecological fiscal transfer proposal. In Poland, presence of protected areas decreases gross boroughs income and stakeholders' annual income from the protected areas compared to the Special Economic Zones (SEZ) municipalities. Designation of the protected areas has not been backed by any appropriate national financial policy while local governments are expected to complete various tasks towards nature conservations on their land while the SEZ boroughs attract potential investors by an economically profitable tax allowance system.

The Council of the Rural Communes of the Republic of Poland representing municipalities situated in the regions with protected areas developed a proposal for a fiscal transfer mechanism - Ecological Subvention Act - a tool of sustainable development policy. The Act proposes ecological subventions - a type of financial compensation for municipalities whose protected parts of the territory are excluded from a business activity. Ecological subventions are to be spent without any limitations on a variety of local governmental needs, and to support a range of local investments. Invested resources would be reimbursed into the national budget in the form of $23 \%$ VAT tax and personal tax to subcontractors. Calculation of ecological subventions would be based on algorithms proposed by the Ministry of Finance, en vertu on a proposed act. It is assumed that completion of the Ecological Subvention Act will result either in extra expenditures or shifting resources within the current national budget. It does not, however, cause, additional expense to local authorities. A total expenditure of national budget for ecological subvention initiative is approximated to be ca. $200 \mathrm{mln}$ EURO. The ecological subvention proposal was widely consulted with General Directorate for Environmental Protection, members of the Polish Parliament, representatives of national and regional governments and lawyers. This bottom-up initiative was also highly regarded by the President of Republic of Poland [42].

Currently the process of designing compensation for designated sites Nature 2000 in Poland, including the Ecological Subvention Act, is focused on municipalities and local governments. However, another contentious issue in the country with regards to Natura 2000 sites is its occurrence on private lands. While defining the potential of conflict over private land involved in conservation in Poland, the following section looks into the existing instruments being explored to deal with private land conservation in other countries. 


\section{Conflicts over conservation on private lands}

From the global perspective, the success of nature protection and in-situ biodiversity conservation relies heavily on protected areas. Since most of these areas are under government authorities and agencies, it has led to the common belief amongst stakeholders that the responsibility of maintaining the functional elements promoting nature conservation lie on the government. However, protected areas in in-situ conservation are limited by the fact that they occupy only $12.5 \%$ of the global land cover [43], often fragmented and isolated from one another, and they support only a fraction of the biodiversity and ecosystem services. In Poland, $32.4 \%$ of the total land area is under some form of legal protection for nature conservation. However, the ownership structure diverges from the conventional assumption that protected areas in the country are usually state owned. For example, $15.9 \%$ of the national parks' land area is under private ownership [44]. It is expected that significant portion of the Natura 2000 areas lie on private land as well $[12,44]$. Hence, the final issue linked to the designation of Natura 2000 areas is the protest of private land owners against rules enforced by the Network that affect their economic wellbeing.

Typically, any planning strategy focuses only on the ecological system and not the broader socio-ecological systems, which is where conservation in reality occurs. Hence, without involving all stakeholders in the decision making process, what needs to be conserved against what can be conserved becomes a debatable issue. Private lands with their larger land coverage, have a strong potential in promoting biodiversity conservation and maintaining habitats and their connectivity [45]. They can make substantial contributions to biodiversity conservation needs and therefore, need to be integrated into the conservation strategies [46]. On the other hand, private land could also be a serious threat to biodiversity due to the deforestation and other land-use changes and more actions need to be directed towards encouraging preservation of nature [47]. In these circumstances, integrating stakeholder participation in planning and decision-making becomes crucial for effective conservation actions. This requires looking towards a more comprehensive bioregional model that conserves landscapes, irrespective of the nature of ownership [48]. However, integrating private land into conservation planning and management is complicated by the nature of ownership of the land and the complex social and economic traits that are interrelated with its current use [49-51]. The land use structure in the Natura 2000 areas lying on private land, for instance, are managed by their owners, chiefly farmers [52]. The issue of private land conservation has been explored through a diverse spectrum of mechanisms such as regulatory prohibitions and requirements including use of legal instruments, government acquisition of land or right over resource use leading to relocation and rehabilitation of previous residents (as observed during the establishment of the first national parks in the USA and still practiced in developing countries such as in Central Africa and South Asia), direct incentives for private conservation action [53-56] or educational programs and public consultations.

Globally, conservation on private land has been one of the main reasons for conflict, as it raises the issue of development and property rights versus the restrictive approach to 
conservation and to address this, both involuntary and voluntary tools have been used. Involuntary actions include relocation of people from private land with conservation value through direct purchase of the land by the government. This is usually accompanied by rehabilitation negotiations between landowners and authorities [55,57]. Another popular tool is regulations or restrictions directed towards landowners on the usage of their land. This top-down approach appears less intrusive, but it is nevertheless an issue of contention over property rights and right of use of the land. Government usually have limited budgets to acquire the land and so they prefer a mixed model of private and public protected areas, where private lands included in protected area are subjected to the same restrictions as public lands [58]. Involuntary acquisition and imposed regulations have been the primary strategies for conservation of nature in Poland. In Natura 2000, the sites have been designated based on their ecological significance and scientific opinion leading to considerable proportion lying on private lands in several EU countries and Poland is no exception $[17,54]$. Usually, the regulations and restrictions imposed over the public land within the park also become applicable to a large extent on the private land situated within the strict protected area [54,58] and subsequently, it has met with strong resistance from private landowners who see no direct benefit from their land being included in protected areas $[17,59]$.

Voluntary tools include new strategies that provide an incentive to landowners to involve them in the process such ilegally establishing private reserves, use of conservation easements, forest certification for forest products and conservation contracts, to name a few [46,54,56,60-66]. The success of these tools in addressing the conflict of development versus conservation has met with a varying degree of success in different regions. While private reserves, including game ranches, are very popular in Africa and in some Central American countries owing to the presence of mega-fauna [64-65,67], the use of conservation easements on the other hand, has been more popularized in developed nations such as USA, Australia and to some extent in the UK $[46,56,63,68]$. The use of such tools has not been documented in Poland or other Central and Eastern Europe countries. One reason could be that use of tools such as conservation easements requires financial support from national or regional authorities in order to compensate for the deficit incurred by local administration in the form of lower tax collection due to tax reliefs that these easements typically offer. This would require their respective governments to direct more financial resources towards nature conservation, and often these nations are limited in their budget. Forest certifications as an incentive based tool also has a global appeal with FAO reporting $7 \%$ of the world's private forests being certified by 2006. International certification agencies such as The Forest Stewardship Council (FSC) have a presence in several countries, including Poland. However, the cost certification and lack of consumer awareness about certified products have been the primary challenges in promoting this tool more efficiently.

Perhaps the most common conservation tool being used in Europe has been the conservation contracts. These binding voluntary agreements are signed between a landowner and a government agency/authority to conserve the natural features on the land, or encourage activities with a conservation core on private land in return for 
incentives such as technical help, finances for weeding etc. Besides national level contracts such as Austria's Natural Forests Reserve Program and Sweden's Nature Conservation Agreements, the largest of tools in terms of its scale is the Agri-Environmental Scheme (AES) under the Common Agricultural Plan (CAP) of the EU. It has been implemented in almost all the EU countries. Since the impetus behind this scheme was to promote improved and environmentally sound agricultural practices, AES specifically targets farmers. France, for instance, developed special compensation measures to make conservation on farmlands more attractive after it received strong opposition from farmers over the designation and implementation of Natura 2000 sites, significant proportion of which lay on farmlands. This change in approach towards implementation of Natura 2000 generated more support and acceptance towards the Natura 2000 network from this particular stakeholder group.

The role of agriculture in employment in Poland has shrunk from $26.4 \%$ in 1984 to $16.2 \%$ in 2005 with a decrease of $5 \%$ in agricultural production; however the trend has begun to stabilise and even increase in case of animal husbandry after the shift from centralised economy in the 1980s to the present market-based economy [69]. Contrary to many other centrally planned economies, Poland's farmlands remained mostly under individual ownership leading to more number of small subsistence farmers. The support from CAP in Poland started in 2004 under the Rural Development Plan (RDP), which included aids in inputs and outputs that minimised intensive agricultural practices considered to be harmful to the environment, and instead it encouraged agricultural activities that were believed beneficial to the environment or had a conservation core.

The National Agri-Environmental Programme (NAEP) under the RDP states protection of environment and landscapes, and conservation of biodiversity as two of its main objectives. To achieve these objectives, direct involvement of farmers and increasing their knowledge about the AES and its principles become crucial (OECD, 2008). NAEP has had positive impacts on stabilizing the country's agricultural production along with environmental benefits. In its new phase, it has undergone major changes (2007-2013) to reach a larger community of farmers and target Natura 2000 sites and non-Natura 2000 sites separately with different benefits [70-71].

NAEP faces two major challenges while promoting conservation on farmlands. Firstly, general lack of awareness among farmers on detrimental environmental impacts of agricultural practices (with only 30\% of farmers being aware of it) [69] and their subsequent impact on biodiversity has been observed as a hindrance in wider coverage of such a scheme. Without being aware of the effects of their practices, farmers are less likely to modify their existing practices. Secondly, most of Poland's farmers are with small land holdings, which makes it difficult for the AES to reach majority of the farmers in Poland: most compensation programs under the AES was available to only $5 \%$ of farmers in its first phase [72] and therefore has not been able to reach a significant proportion of private lands that could have an important role in conservation. This challenge in particular highlights the importance of context specific policies to be able to address the situation on ground. 
Different tools to promote private land conservation has met with varying degree of success in different countries or region and this fact only emphasises that these tools are context dependent, including the regional context (the country, political history, economic status) and the type of stakeholders involved. While it is generally accepted that defining areas of conservation priority depends on the level of ecological awareness along with political will, the success of conservation initiatives on such areas is a function of the human and social dimensions, such as stakeholders' willingness and capacity to participate [50,73]. It is therefore imperative to differentiate between areas of conservation priority and that of conservation opportunity. Conservation areas with high ecological value as well as high social value require minimal intervention through external aids or tools; however, areas with high ecological value and low social value will require some incentives to make conservation more attractive and plausible [50,74].

In Poland, especially in the case designation of Natura 2000 sites, biological significance has been the criterion for designating areas for conservation. However, the real potential of what can be conserved remains questionable. With $19.26 \%$ of the total Natura 2000 area lying on agricultural land [75], imposing restrictions on land use cannot be the solution. Already, there have been several instances of protest and hostility towards the Natura 2000 network, and this can be attributed to the fact that the process of site designation did not allow for stakeholder participation [17]. Lack of awareness about the Natura 2000 Network adds further to this hostility since landowners now understand the program only as an intrusion into their private space and a violation of their property rights [59]. Although drafting the management plans for these sites through a consultation process is now a legal requirement, thereby allowing for stakeholder participation, successful outcome of such an initiative is often hindered by the fact that the most consultation processes are not handled properly, coupled with the preconceived notion among stakeholders about such protected areas being a hindrance to livelihoods and property rights, which makes the process difficult.

The overall land use structure in Europe has been changing to accommodate for the economic development, and although forest land cover has increased, only $1.6 \%$ of the continent's natural forests are protected legally [76- 77]. Poland is no exception to this developmental trend and with its accession to the EU, intensification of certain practices such as those in agriculture is expected. In such a situation, involvement of people in conservation will play an important role in furthering conservation goals [51]. Besides political support at a national level, and financial support at a regional level, it is necessary to find stakeholders supporting long-term sustainable implementation of management plans for protected areas located on private lands.

The authors pose that policy-makers need to identify the factors that increase stakeholders' acceptance of conservation practices on their private land. This will require the research into socio-demographic and economic features of landowners as well as land characteristics (type of land use, type of protected area) [50]. The challenge in private land conservation is to promote conservation values on a land without compromising its capability to meet the requirements of the owners from it. Tools and mechanisms that compensate for the 
conservation opportunity and that increase social acceptance of the 'protected areas on private land' model are necessary under circumstances where ecologically significant private land in Poland generates direct or indirect economic benefits to its owners.

\section{Conclusions}

The new environmental policy can only be successful in the Central and Eastern European countries if it is legitimate. Therefore, Poland as well as other post-communist democracies need to re-focus its environmental policy practices toward community empowerment in environmental decision-making which is conceptualized as a process in which community members, who share physical spaces, experiences and concerns, gain influence over conditions that matter to them [78]. Good policy-making requires, among others, up-to-date knowledge or assessment of the "winners" and "losers". Furthermore, its implementation at the local level requires local skills and local resources. The authors propose that legitimate policy must empower communities through participation in environmental management decision-making.

Community used to be defined as a geographic concept or a form of a collective interest revealed in common views on some issues [79]. The authors understand a community as: "the process of interactions through time with direction toward some more or less distinctive outcomes and with constantly changing elements and structure" [80]. By definition, a community is a process in which community participants focus on the betterment of local stakeholders in the context of the Natura 2000 program.

Scholars suggest that direct participation in decision-making is a condition for individual empowerment [81-82] . Others add that non-direct forms of participation in decision-making can also empower stakeholders [82-83]. Local participation has been a concept of increasing importance since the Brundtland Report in 1987 defined it as an indispensable ingredient of sustainable development. Public participation is consistent with the three-dimensional concept of sustainable development as it allows natural capital to be traded off for economic and social capital. It allows residents to observe more closely and evaluate the current governance system in a better way [84-85]. Such distribution of the decision-making power towards local stakeholders integrates democratic elements into sustainable development of the rural post-communist areas in Poland [86].

Participatory decision-making is a key element of the local democratic practice. As much as literature in recent years emphasizes the need for inclusion of stakeholders in decisionmaking, it also indicates the importance of fundamental arrangements for this community based management and development. Shared control through the inclusion of community members in decision-making is a key element of empowerment [87]. Authorities that attempt to involve community in decision-making in natural resources management must be able and willing to learn from the community members and to apply instruments that empower residents [88-89]. In Poland, the practice of empowering Natura 2000 stakeholders is still in its infancy. Also scholars from social disciplines rarely mention the idea of empowering stakeholders in the context of changing social and political environment of rural Poland. 
Discussed difficulties that the majority of the EU Members have experienced in regards to Natura 2000 Network implicate the more global issues associated with the implementation of sustainable development principles and the practice of empowering stakeholders. The core problem of the current approach to Natura 2000 Network as well as other initiatives toward more sustainable Europe is the decentralization of responsibilities for protection of local nature and simultaneous top-down environmental decision-making that facilitates policy creation at the national-level. Hence, EU must focus on legitimate environmental protection policies by distributing rights over environmental decisions to local authorities and other local stakeholders. Also, the efficiency of existing decision-making tools to mitigate and prevent current or future conflicts regarding Natura 2000 Network needs to be re-examined in the context of transitioning economies of the Central and Eastern European Members of the EU such as Poland. The authors propose empowering stakeholders for Natura 2000 through participation in decision-making processes as a locally implemented solution to this global problem.

In addition to increasing legitimization new environmental policies that follow Natura 2000 itself, public participation leads to the development of multilevel governance in the broader and more interdisciplinary context, the introduction of new institutional structures and financial resources to the civil society [90-91]. The non-homogenous character of a community is the main identified barrier to its successful participation in decision-making [92-93]. To date debates, information sharing and creating space for public opinion are the main instruments of participatory approaches [94]. Collaboration and dialogue with governmental representatives create conditions for equity and thereby space for community feedback and community input in decision making that flows upward toward officials $[84,85]$. Jointly derived decisions contribute to trust building within community [95-96].

Solving problems at the central level proved so far ineffective, and currently documents such as Strategy for Sustainable Development of Poland till 2025 more explicitly articulate that local leadership institutions need to engage stakeholders in the development in order to achieve local sustainability. The Habitat Directive and the Convention of Aarhus [97-98] notes that public participation should manifest itself in society's access to information about the natural environment and its involvement in successive stages of the implementation of protective measures: from planning to making decisions in management. Moreover, bottom-up approaches to biodiversity management will increase stakeholders' perceived control over the local natural environment and increase felt responsibility for its quality.

\section{Author details}

Małgorzata Grodzińska-Jurczak, Sristi Kamal and Justyna Gutowska Institute of Environmental Sciences, Jagiellonian University, Kraków, Poland

Marianna Strzelecka

College of Merchandising, Hospitality and Tourism, University of North Texas, Denton, TX, USA 


\section{Acknowledgement}

The following manuscript was developed as part of the research project "Information, education and communication for the natural environment" sponsored by the Jagiellonian University (grant no. WRBW/DS/INoŚ/760).

\section{References}

[1] Larobina MD. A report on Poland and European union accession. Multinational Business Review (ISSN: 0-333-71654-X) 2001;9(2) 8-16.

[2] Kluvánková-Oravská T, Chobotová V, Banaszek I. From Government to Governance for Biodiversity: The Perspective of Central and Eastern European Transition Countries. Environmental Planning and Governance (ISSN: 1756-9338) 2009;19 186-196.

[3] Mannigel E. Integrating Parks and People: How Does Participation Work in Protected Area Management? Society \& Natural Resources (ISSN: 0894-1920) 2008;21(6) 498-511.

[4] Paavola J, Kluvánková-Oravská T, Gouldson A. Institutions, ecosystems and the interplay of actors, scales, frameworks and regimes. Environmental Policy and Governance (ISSN: 1756-9338) 2009;19 141-147.

[5] Harwood J. Risk assessment and decision analysis in conservation. Biological Conservation (ISSN: 0006-3207) 2000;95 219-226.

[6] Mascia MB. Conservation and the Social Science, Editorial. Conservation Biology (ISSN: 0888-8892) 2003;17(3) 649-650.

[7] Ostrom E. Governing the commons: The evolution of institutions for collective action. Cambridge: Cambridge University Press (ISSN: 00029092); 1990.

[8] Hiedenpää J. European-wide conservation versus local well-being: the reception of the Natura 2000 Reserve Network in Kavia, SW-Finland. Landscape and Urban Planning (ISSN: 0169-2046) 2002;61 113-123.

[9] Weber N, Christophersen T. The influence of non-governmental organisations on the creation of Natura 2000 during the European Policy process. Forest Policy and Economics (ISSN: 1389-9341) 2002;4(1) 1-12.

[10] European Commission. Natura 2000 Barometer-update August 2011, Natura 2000 Newsletter (ISSN: 1026-6151) 2012;31 8-9.

http://ec.europa.eu/environment/nature/info/pubs/docs/nat2000newsl/nat31_en.pdf (accessed 15 May 2012).

[11] European Commission. Nature and Biodiversity Cases - Ruling of the European Court of Justice. Luxembourg: Office for Official Publications of the European Communities (ISBN: 92-79-02561-9) 2006.

http://ec.europa.eu/environment/nature/info/pubs/docs/others/ecj_rulings_en.pdf

[12] Generalna Dyrekcja Ochrony Środowiska (General Directorate for Environmental Protection) 2010. Online press release.

http://www.gdos.gov.pl/Articles/view/1910/Historia_powstania

[13] Stoll-Kleemann S. Opposition to the designation of protected areas in Germany. Journal of Environmental Planning and Management (ISSN: 1360-0559) 2001;44 111-130.

[14] Henle K, Didier AD, Clitherow J, Cobb P, Firbank L, Kull T, McCracken D, Moritz RFA, Niemela J, Rebane M, Wascher D, Watt A, Young J. Identifying and managing the 
conflicts between agriculture and biodiversity conservation in Europe-A review. Agriculture, Ecosystems and Environment (ISSN: 0167-8809) 2008;124 60-71.

[15] Alphandéry P, Fortier A. Can a Territorial Policy be Based on Science Alone? The System for Creating the Natura 2000 Network in France. Sociologia Ruralis (ISSN:14679523) 2001;41(3) 311-328.

[16] Nieminen M. BiofACT - Finnish report, University of Jyvaskyla, Department of Social Sciences and Philosophy, Jyvaskyla 2004. http:// www.ecnc.nl/file_handler /documents/original/download (accessed 20 September 2006).

[17] Grodzińska-Jurczak M, Cent J. Udział społeczny szansą dla realizacji programu Natura 2000 w Polsce. Public participatory approach - a Chance for Natura 2000 implementation in Poland. Chrońmy Przyrodę Ojczystą (ISSN: 0009-6172) 2010;66(5) 341-352.

[18] Makomaska-Juchiewicz M. Sieć obszarów Natura 2000 w Polsce. In: Gregorczyk M. (ed.) Integralna Ochrona Przyrody (ISBN: 9788391891490). Kraków: Instytut Ochrony Przyrody PAN; 2007. p165-176.

[19] Lawrence A. Experiences with participatory conservation in post-socialist Europe. International Journal of Biodiversity Science and Management (ISSN: 1745-1590) 2008;4 179-186.

[20] Bell S, Marzano M, Cent J, Kobierska H, Podjed D, Vandzinskaite D, Reinert H, Armaitiene A, Grodzinska-Jurczak M, Mursic R. What Counts? Volunteers and their organisations in the recording and monitoring of biodiversity. Biodiversity and Conservation (ISSN: 1572-9710) 2008;17(14) 3443-3454.

[21] Cent J, Kobierska H, Grodzińska-Jurczak M, Bell S. Who is responsible for Natura 2000 in Poland? - a potential role of NGOs in establishing the programme. International Journal of Environment and Sustainable Development (ISSN: 1478-7466) 2007;6 422-435.

[22] Jermaczek A., Pawlaczyk P. Natura 2000 - narzędzie ochrony przyrody. Planowanie ochrony obszarów Natura 2000. Warszawa: WWF Polska; 2004.

[23] Dimitrakopoulos PG, Memtsas D, Troumbis AY. Questioning the effectiveness of the Natura 2000 Species Areas of Conservation strategy: the case of Crete. Global Ecology and Biogeography (ISSN: 1466-8238) 2004;13 199-207.

[24] Bernacka A., Jermaczek A., Kierus M., Ruszlewicz A. Uspołecznione planowanie ochrony przyrody na obszarach sieci NATURA 2000. (Social plans of nature protection at NATURA 2000 sites). Świebodzin: Wydawnictwo Klubu Przyrodników (ISSN: 1230509X); 2004.

[25] Baranowski M. Prace nad siecią NATURA 2000 w Polsce. In: Makomaska-Juchiewicz M., Tworek S. Ekologiczna Sieć Natura 2000. Problem czy szansa? Kraków: Instytut Ochrony Przyrody; 2003.

[26] Grodzińska-Jurczak M, Cent J. Expansion of Nature Conservation Areas: Problems with Natura 2000 Implementation in Poland? Environmental Management (ISNN: 0364152X) 2011;47 11-27.

[27] Grodzińska-Jurczak M. Rethinking of nature conservation policy in Poland - the need of human dimension approach. Human Dimensions of Wildlife (ISSN: 1533-158X) 2008;13(5) 380-381.

[28] Trzeciak M. Projektowane regulacje prawne zagrożeniem dla ochrony przyrody. (Risk of proposed regulations to the nature protection). Przyroda Polska (ISSN: 0552-430X) 2005;2. 
[29] Kronenberg J., Bergier T., editors. Wyzwania zrównoważonego rozwoju w Polsce. Kraków: Fundacja Sendzimira (ISBN: 978-83-62168-00-2); 2010.

[30] Cent J, Grodzińska-Jurczak M, Nowak N. Ocena efektów małopolskiego programu konsultacji społecznych wokół obszarów Natura 2000. Chrońmy Przyrodę Ojczystą (ISSN: 0009-6172); 2010;66(4) 251-260.

[31] Pawlaczyk P., Jermaczek A. Natura 2000 - narzędzie ochrony przyrody. Planowanie ochrony obszarów Natura 2000. Warszawa: WWF Polska; 2004.

[32] Bołtromiuk A. Uwarunkowania zrównoważonego rozwoju gmin objętych siecią Natura 2000 w świetle badań empirycznych. Warszawa: Instytut Rozwoju Wsi i Rolnictwa Polskiej Akademii Nauk (ISSN/ISBN: 83-89 900-41-6); 2011.

[33] Bołtromiuk A., Kłodziński M. Natura 2000 jako czynnik zrównoważonego rozwoju obszarów wiejskich regionu Zielonych Płuc Polski. Warszawa: Instytut Rozwoju Wsi i Rolnictwa Polskiej Akademii Nauk (ISSN/ISBN: 83-89900-40-8); 2011.

[34] Ring I. Compensating Municipalities for Protected Areas Fiscal Transfers for Biodiversity Conservation in Saxony, Germany. GAIA (ISSN: 0940-5550) 2008;17(S1) 143-151.

[35] Ring I, Drechsler M, van Teeffelen AJA, Irawan S, Venter O. Biodiversity conservation and climate mitigation: what role can economic instruments play? Current Opinion in Environmental Sustainability (ISSN: 1877-3435) 2010;2 50-58.

[36] Santos R, Ring I, Antunes P, Clemente P. Fiscal transfers for biodiversity conservation: the Portuguese Local Finances Law. UFZ-Diskussionspapiere 2010 (ISSN: 1436-140X);11.

[37] Björkell S. Resistance to Top-Down Conservation Policy and the Search for New Participatory Models. The Case of Bergö-Malax' Outer Archipelago in Finland. In: Keulartz J., Leistra G. (eds.) Legitimacy in European Nature Conservation Policy. Case Studies in Multilevel Governance (ISSN: 1570-3010). Wageningen, The Netherlands: Springer; 2007. p109-126.

[38] Fisher R.J. Collaborative management of forests for conservation and development. Issues in forest conservation (ISSN: 1436-140X). Gland, Switzerland: IUCN and WWF; 1995.

[39] Kellert SR, Mehta JN, Ebbin SA, Lichtenfeld LL. Community natural resource management: promises, rhetoric and reality. Society and Natural Resources (ISSN: 15210723) 2000;13 705-715.

[40] Chmielewski T.J. Nature conservation management: from idea to practical results. Lublin, Łódź, Helsinki, Aarhus: Alternet, PWZN; 2007.

[41] Najwyższa Izba Kontroli. Informacja o wynikach kontroli wdrażania ochrony na obszarach Natura 2000. http://www.nik.gov.pl/kontrole/wyniki-kontroli-nik/ kontrole,1664.html

[42] Związek Gmin Wiejskich Rzeczypospolitej Polskiej. Subwencja ekologiczna. http://www.gminyrp.pl/?slang=pl\&art=1\&m=7\&p=2\&id=626 (accessed 2 February 2012).

[43] World Database on Protected Areas. Regional and Global Stats for 1990-2010 from the 2011 MDG Analysis. Cambridge, UK: UNEP-WCMC; 2011.

[44] Central Statistical Office. Statistical Information and Elaboration. Warsaw: Environment (ISSN: 0867-3217); 2011.

[45] Smith G, Phillips E, Doret G. Biodiversity Conservation on Private Land: conference proceedings, 14-18 September 42nd ISoCaRP Council Case Studies. Hague, Netherlands: ISoCaRP; 2006. 
[46] Clough P. Encouraging private biodiversity: Incentives for biodiversity conservation on private land. Report to the Treasury, New Zealand Institute of Economic Research, Wellington, New Zealand; 2000.

[47] Mieners RE, Parker DP. Legal and economic issues in private land conservation. Natural Resources Journal (ISSN: 1477-8947) 2004;44 353-360.

[48] Figgis P. Conservation on Private Lands: the Australian Experience. Gland, Switzerland and Cambridge, UK: IUCN (ISBN: 2-8317-0779-X); 2004.

[49] Knight RL. Private lands: the neglected geography. Conservation Biology (ISSN: 08888892) 1999;13 223-224.

[50] Raymond CM, Brown G. Assessing Conservation Opportunity on Private Land: Socioeconomic, behavioural and spatial dimensions. Journal of Environmental Management 2011;92(10) 2513-2523.

[51] Tikka PM, Kauppi P. Introduction to special issue: protecting nature on private lands - from conflict to agreements. Environmental Science and Policy (ISSN: 1462-9011) 2003; 6 193-194.

[52] Makomaska-Juchiewicz M, Tworek S. Ekologiczna sieć Natura 2000. Problem czy szansa? Kraków: Instytut Ochrony Przyrody PAN (ISSN: 0009-6172); 2003.

[53] Kauneckis D, York AM. An Empirical Evaluation of Private Landowner Participation in Voluntary Forest Conservation Programs. Environmental Management (ISSN: 0364152X) 2009;44 468-484.

[54] Mayer AL, Tikka PM. Biodiversity conservation incentive programs for privately owned forests. Environmental Science and Policy 2006 (ISSN: 1462-9011);9 614-625.

[55] Rangarajan M, Shahabuddin G. Displacement and Relocation from Protected Areas: Towards a Biological Historical Synthesis. Conservation and Society (ISSN: 09724923) 2006;4 359-378.

[56] Rissman AR, Lozier L, Comendant T, Kareiva P, Kiesecker JM, Shaw RM, Merenlender AM. Conservation Easements: Biodiversity Protection and Private Use. Conservation Biology (ISSN: 09724923) 2007;21(3) 709-718.

[57] Karnath KK. Bhadra Wildlife Sanctuary: Addressing Relocation and Livelihood Concern. Economic and Political Weekly (ISSN: 0012-9976) 2005;40(6) 4809-4811.

[58] Environmental Law Institute. Legal Tools and Incentives for Private Lands in Latin America: Building Models for Success. Washington, DC, USA: Environmental Law Institute (ISBN: 1-58576-059-5). http://www.elistore.org/reports_detail.asp?ID510914

[59] Pietrzyk-Kaszyńska A, Grodzińska-Jurczak M, Szymańska M. Factors influencing perception of protected areas - the case of Natura 2000 in Polish Carpathian Communities. Journal for Nature Conservation (ISSN: 1617-1381) 2012 (forthcoming).

[60] Cubbage F, Diaz D, Yapura P, Dube F. Impacts of Forest Management Certification in Argentina and Chile. Forest Policy and Economics (ISSN: 1389-9341) 2009;12(7) 497-504.

[61] Doremus H. A policy portfolio approach to biodiversity protection on private lands. Environmental Science \& Policy (ISSN: 1462-9011) 2003;6 217-232.

[62] Forest Stewardship Council. Country specific units: Poland 2011. http://www.fsc.org (accessed 18 January 2012).

[63] Gattuso D.J. Conservation Easements: The Good, The Bad and The Ugly. USA: National Policy Analysis, National Centre for Public Policy Research; 2008.

[64] Langholz J, Lassoie J. Perils and Promise of Privately Owned Protected Areas. Bioscience (ISSN: 0006-3568) 2001;51 1079-1080. 
[65] Ramutsindela M. Parks and People in Post-Colonial Societies: experiences in Southern Africa. Springer (ISBN: 1-4020-2843-1); 2004.

[66] Stolton S., Mansourian S., Dudley N. Valuing Protected Areas. Washington DC: The World Bank; 2010.

http://www.cropwildrelatives.org/fileadmin/www.cropwildrelatives.org/documents/ Valuing\%20Protected\%20Areas.pdf (accessed 24 December 2011)

[67] Langholz J, Krug W. New Forms of Biodiversity Governance: Non-state actors and the Private Protected Area Action Plan. Journal of International Wildlife Law and Policy (ISSN: 1388-0292) 2005;7 9-29.

[68] Reid CT. The Privatisation of Biodiversity? Possible New Approaches to Nature Conservation Law in the UK. Journal of Environmental Law (ISSN: 0952-8873) 2011;23(2) 203-231.

[69] OECD. Environmental Performance of Agriculture in OECD countries since 1990. Paris, France: OECD; 2008.

[70] Goliński P., Golińska B. Agri-environmental funding schemes - a tool for supporting the conservation of semi-natural grassland in Poland; 2011. http://www.egf2011.at/files/pubs/592_golinski.pdf (accessed: 6 February 2012).

[71] Liro A. Conditions of natural environment in rural areas. In: Wilkin J., Nurzyńska I. (eds.) Rural Poland 2010, Rural Development Report. Warsaw: Foundation for the Development of Polish Agriculture; 2010, p95-120.

[72] BirdLife International. Agri-environment schemes and biodiversity: lessons learnt and examples from across Europe.

http://www.birdlife.org/eu/pdfs/Agrienvironment_schemes_lesson_learnt.pdf (accessed: 8 February 2012).

[73] Paloniemi R, Tikka PM. Ecological and social aspects of biodiversity conservation on private lands. Environmental Science and Policy (ISSN: 1388-0292) 2008;11 336-346.

[74] Knight AT, Cowling RM, Difford M, Campbell BM. Mapping human and social dimensions of conservation opportunity for the scheduling of conservation action on private land. Conservation Biology (ISSN: 0888-8892) 2010;24 1348-1358.

[75] Herbut E, Walczak J. Ekstensywne rolnictwo w Polsce: conference proceedings, 18-27 February 2008, XV science conference. Postęp naukowo- techniczny i organizacyjny w rolnictwie, Zakopane, Poland. 2008.

[76] Larsson TB. Biodiversity Evaluation Tools for European Forests. Ecological Bulletins (ISBN-10: 8716164342) 2001;50.

[77] Niemelä J. Identifying managing and monitoring conflicts between forest biodiversity conservation and other human interests in Europe. Forest Policy and Economics (ISSN: 1389-9341) 2005;7(6) 877-890.

[78] Fawcett SB, Paine-Andrews A, Francisco VT, Schultz JA, Richter KP, Lewis RK, Williams EL, Harris KJ, Berkley JY, Fisher JL, Lopez CM. Using empowerment theory in collaborative partnership for community health and development. American Journal of Community Psychology (ISSN: 0091-0562) 1995;23(5) 677-697.

[79] George W.E., Mair H., Reid D.G. Rural tourism development: Localism and cultural change. Bristol, Buffalo, Toronto: Channel View Publications; 2009.

[80] Wilkinson KP. The community as a social field. Social Forces (ISSN: 0037-7732) 1970;48(3) 9-17. 
[81] Pratchett L, Durose C, Lowndes V, Smith G, Stoker G, Wales C. Empowering communities to influence local decision-making: A systematic review of the evidence. Department for Communities and Local Government 2009.

http://www.communities.gov.uk/documents/localgovernment/pdf/1241955 (accessed 01 February 2012).

[82] Zimmerman MA, Rappaport J. Citizen participation, perceived control, and psychological empowerment. American Journal of Community Psychology 1988;16(5) 725-750.

[83] Li WJ. Community decision-making participation in development. Annals of Tourism Research (ISSN: 0160-7383) 2006;33(1) 132-143.

[84] Cole S. Information and Empowerment: The Keys to Achieving Sustainable Tourism. Journal of Sustainable Tourism (ISSN: 0966-9582) 2006;14(6) 629-644.

[85] Tosun C, Timothy D. Arguments for community participation in tourism development. Journal of Tourism Studied (ISSN: 0974-6250) 2003;14(2) 2-11.

[86] Bora A, Hausendorf H. Participatory science governance revisited: normative expectations versus empirical evidence. Science and Public Policy (ISSN: 0302-3427) 2006;33(7) 478-488.

[87] Knopp TB, Caldbeck ES. The role of participatory democracy in forest management. Journal of Forestry (ISSN: 0022-1201) 1990;88(5) 13-19.

[88] Armitage DR. Community-cased Narwhal management in Nunavut, Canada: Change, uncertainty, and adaptation. Society \& Natural Resources (ISSN: 0894-1920) 2005;18(8) 715-731.

[89] Austin RL, Eder JF. Environmentalism, development, and participation on Palawan Island, Philippines. Society \& Natural Resources (ISSN: 0894-1920) 2007;20(4) 363-371.

[90] Antoniewicz P. Partnerstwo czlowieka i przyrody, Dolnośląska Fundacja Ekorozwoju. http://www.iee.org.pl/rozwoj/docs/PARTNERSTWO_CZLOWIEKA_I_PRZ.pdf

[91] McCauley D. Sustainable development and the governance challenge: the French experience with Natura 2000. European Environment (ISSN: 0961-0405) 2008;18(3) 152-167.

[92] Agrawal A, Gibson G. Enchantment and disenchantment: The role of community in natural resource conservation. World Development (ISSN: 0305-750X) 1999;27 629-649.

[93] Walker PA, Patrick T, Hurley PT. Collaboration derailed: The Politics of "communitybased" resource management in Nevada County. Society \& Natural Resources (ISSN: 0894-1920) 2004;17(8) 735-751.

[94] Reid DG, Mair H, George W. Community tourism planning: A self-assessment instrument. Annals of Tourism Research 2004;31(3) 623-639.

[95] Lachapelle PR, McCool SF, Patterson ME. Barriers to effective natural resource planning in a "messy" world. Society \& Natural Resources (ISSN: 0894-1920) 2003;16(6) 473-490.

[96] Smith PD, McDonough MH. Beyond public participation: Fairness in natural resources decision making. Society and Natural Resources (ISSN: 0894-1920) 2001;14 239 -241.

[97] Stec S., Casey-Lefkovitz S., Jendrośka J. (editors.) The Aarhus Convention - An Implementation Guide. New York and Geneva (ISBN: 9211167450 9789211167450) 2000: Channel View Publications.

[98] Dziennik Ustaw - year 2003, nr 78, item 706 from day 2003-05-09. 